\title{
CHEMICAL COMPOSITION OF ESSENTIAL OILS OF ANNONA SQUAMOSA L. AND ANNONA RETICULATA L. FROM VIETNAM
}

\author{
TRAN MINH HOI \\ Institute of Ecology and Biological Resources \\ DO NGOC DAI, TRAN DINH THANG \\ Vinh University
}

The Annonaceae, a pantropic family, is well developed in the tropics and is subtropics of both New and Old World. Only a few species are distributed in warm temperature (Asiminia) and the islands of the Pacific. The Annonaceae is one of the largest family that include 130 genera and over 2300 species in the world, and the greatest number of genera and species is concentrated in Indo-Malaysian area of Asia $[7,13]$. Economically, this family is an important source of edible fruits and oils, raw material for perfumery and folk medicine for various purposes [8].

The genus Annona is one of important genus of the family Annonaceae. This genus consists of about 125 species, widely distributed in Asia and Australia, American, Africa, especially in South East Asia, such as, Malaysia, Indonesia, Thailand and Indochina [3].

Some authors have investigated the composition of Annona squamosa and $A$. reticulata: Chavan M. J., Shinde D. B., Nirmal S. A. [4], Andrade H. A., Zoghbi M. B., Maia G. S., Fabricius H. and Marx F. [2], Ogunwande Isiaka A., Ekundayo A., Olusegun Olawore, Nureni O., Kasali Adeleke A. [10], Pino J. A., Aguero J., Marbot R. [11].

\section{MATERIAL AND METHODS}

\section{Meterial}

The leaves of Annona squamosa L., Annona reticulata L. were collected in April 2007, in Thanh Hoa and Nghe An provinces. A voucher specimen (DD110-DD111) was deposited at the Herbarium of the Institute of Ecology and Biological Resources and Vinh University.
Fresh leaves were shredded and their oils were obtained by steam distillation for $3 \mathrm{~h}$ at normal pressure, according to the Vietnamese Pharmacopoeia, 1997 [9].

\section{GC/MS}

An Agilent Technology HP 6890N Plus Chromatograph was fitted with a fused silica capillary column HP-5 MS column $(30 \mathrm{~m} \times 0.25$ $\mathrm{mm}$, film thickness $0.25 \mu \mathrm{m})$. The condition of use was the same as described above with $\mathrm{He}$ as carrier gas, and interface with a mass spectrometer HP 5973 MSD (70eV). The temperature was programmed as reported above. Components identification was carried out by comparing MS data with those reported in Library Willey on Chemstation HP [10-13].

\section{RESULTS AND DISCUSSION}

The content of essential oil of Annona squamosa is $0.15 \%$ (fresh leaves) and of $A$. reticulata is $0.20 \%$ (fresh leaves).

The compounds detected in the leaf oil of Annona squamosa and $A$. reticulata from Vietnam are listed in table 1 . Of the total 76 oil components, thirty five were identified in leaf oil of $A$. reticulata, that make up about $92.4 \%$. The major constituent of the essential oil was $\beta$ elemene $(36.5 \%)$. This major compound was accompanied by lesser quantities of germacrene $\mathrm{D} \quad(16.0 \%), \quad \beta$-caryophyllene $(5.3 \%), \quad \beta$ bourbonene $(4.7 \%), \alpha$-copaene $(4.3 \%)$. Other compounds consist with amount lesser than $1.0 \%$ to trace.

By analysing essential oil of the 
A. squamosa the presence of $\beta$-caryophyllene (20.0\%), camphene (11.5\%), $\alpha$-pinene $(4.3 \%)$, $\alpha$-humulene $(3.7 \%), \quad \alpha$-cadinol $(3.7 \%), \quad \delta$ - elemene (3.5\%), bicyclogermacrene $(3.4 \%)$ cadina-1,4-diene $(3.4 \%), \beta$-elemene $(3.2 \%)$ and cyperene $(3.2 \%)$ was revealed.

Table

Chemical constituents of essential oils of Annona squamosa and A. reticulata from Vietnam

\begin{tabular}{|c|c|c|c|c|}
\hline $\mathbf{N}^{0}$ & Compounds & KI & A. squamosa & A. reticulata \\
\hline 1 & Tricyclene & 926 & 0.4 & - \\
\hline 2 & $\alpha$-thujene & 931 & 0.1 & 0.4 \\
\hline 3 & $\alpha$-pinene & 939 & 4.3 & 1.0 \\
\hline 4 & Camphene & 953 & 11.5 & 0.6 \\
\hline 5 & Sabinene & 976 & trace & 1.8 \\
\hline 6 & 6-methyl-5-hepten-2-one & 978 & 0.1 & - \\
\hline 7 & $\beta$-pinene & 980 & 0.6 & 0.5 \\
\hline 8 & myrcene & 990 & 0.2 & 0.8 \\
\hline 9 & $\alpha$-phellandrene & 1006 & trace & 0.1 \\
\hline 10 & $\delta^{3}$-carene & 1011 & trace & - \\
\hline 11 & $\alpha$-terpinene & 1017 & 0.2 & 0.2 \\
\hline 12 & Anisole & 1019 & trace & - \\
\hline 13 & p-ocymene & 1026 & 0.1 & 0.1 \\
\hline 14 & limonene & 1032 & 2.1 & 0.7 \\
\hline 15 & $(Z)-\beta$-ocimene & 1042 & 0.2 & 0.6 \\
\hline 16 & (E)- $\beta$-ocimene & 1052 & 0.4 & 0.9 \\
\hline 17 & $\gamma$-terpinene & 1061 & trace & 0.3 \\
\hline 18 & terpinolene & 1090 & 0.1 & 0.2 \\
\hline 19 & linalool & 1100 & 0.1 & - \\
\hline 20 & alloocimene & 1128 & trace & 0.4 \\
\hline 21 & camphor & 1145 & 0.1 & - \\
\hline 22 & borneol & 1167 & 0.1 & - \\
\hline 23 & rosefurane & 1177 & trace & - \\
\hline 24 & $\alpha$-terpineol & 1191 & trace & - \\
\hline 25 & trans-caveol & 1217 & 0.1 & - \\
\hline 26 & geraniol & 1253 & 0.1 & - \\
\hline 27 & enethol & 1253 & - & 0.1 \\
\hline 28 & bornyl acetate & 1289 & 0.4 & - \\
\hline 29 & Tridecane & 1300 & Trace & - \\
\hline 30 & Z-citral & 1318 & 0.2 & - \\
\hline 31 & cycloisolongifolene & 1319 & 0.7 & - \\
\hline 32 & bicycloelemene & 1327 & - & 2.0 \\
\hline 33 & $\delta$-elemene & 1340 & 3.5 & - \\
\hline 34 & $\alpha$-cubebene & 1351 & 0.2 & 0.6 \\
\hline 35 & cyclosativene & 1371 & - & 0.3 \\
\hline 36 & $\alpha$-copaene & 1378 & 1.0 & 4.3 \\
\hline 37 & $\beta$-bourbonene & 1385 & 2.2 & 4.7 \\
\hline 38 & $\beta$-cubebene & 1388 & 1.3 & 1.8 \\
\hline 39 & $\beta$-elemene & 1391 & 3.2 & 36.5 \\
\hline 40 & Cyperene & 1399 & 3.2 & - \\
\hline
\end{tabular}




\begin{tabular}{|c|c|c|c|c|}
\hline 41 & $\alpha$-gurjunene & 1412 & - & 0.3 \\
\hline 42 & $\beta$-caryophyllene & 1419 & 20.0 & 5.3 \\
\hline 43 & $\gamma$-elemene & 1437 & trace & - \\
\hline 44 & aromadendrene & 1441 & 0.4 & 0.3 \\
\hline 45 & $\alpha$-humulene & 1454 & 3.7 & 1.2 \\
\hline 46 & $\alpha$-patchoulene & 1457 & 0.8 & - \\
\hline 47 & $\gamma$-muurolene & 1480 & 0.1 & - \\
\hline 48 & germacrene D & 1480 & 2.5 & 16.0 \\
\hline 49 & $\alpha$-amorphene & 1485 & 2.4 & - \\
\hline 50 & $\beta$-selinene & 1490 & 0.6 & - \\
\hline 51 & $\delta$-selinene & 1493 & 0.9 & - \\
\hline 52 & bicyclogermacrene & 1495 & 3.4 & 0.2 \\
\hline 53 & cadina-1,4-diene & 1496 & 0.3 & - \\
\hline 54 & $\alpha$-muurolene & 1500 & 0.8 & - \\
\hline 55 & $\alpha$-farnesene & 1506 & - & 0.2 \\
\hline 56 & germacrene $\mathrm{A}$ & 1509 & - & 0.3 \\
\hline 57 & $\gamma$-cadinene & 1514 & - & 0.2 \\
\hline 58 & $\delta$-cadinene & 1525 & 2.0 & 0.8 \\
\hline 59 & cadina-4,9-diene & 1532 & - & 2.0 \\
\hline 60 & Nerolidol & 1533 & 0.3 & 0.3 \\
\hline 61 & $\alpha$-cadinene & 1539 & 0.1 & - \\
\hline 62 & Elemol & 1550 & 0.2 & - \\
\hline 63 & Germacrene B & 1561 & 0.1 & - \\
\hline 64 & trans-isoelemicine & 1570 & 0.1 & 0.1 \\
\hline 65 & spathoulenol & 1576 & 1.6 & 0.5 \\
\hline 66 & caryophyllene oxide & 1583 & 1.4 & 0.6 \\
\hline 67 & Viridiflorol & 1593 & 0.2 & - \\
\hline 68 & $\beta$-oplopenone & 1608 & 0.2 & - \\
\hline 69 & aromadendren epoxide & 1623 & 0.2 & - \\
\hline 70 & $\alpha$-cadinol & 1641 & 3.7 & 0.5 \\
\hline 71 & $\alpha$-selina-6-en-4-ol & 1648 & 0.2 & - \\
\hline 72 & Heptadecane & 1700 & 1.1 & - \\
\hline 73 & Calamenene & 1702 & 0.2 & - \\
\hline 74 & Farnesol & 1718 & 0.2 & - \\
\hline 75 & Mitsulfit & 1741 & 0.1 & - \\
\hline 76 & Octadecane & 1800 & 0.3 & - \\
\hline
\end{tabular}

Notes: KI. Kovas Index; trace $<0.1$.

According to Ogunwande Isiaka A. et al. (1992), [10] oil obtained by hydrodistillation from the leaves of A. reticulata $\mathrm{L}$. consists of 18 monoterpenes amounting to $29.0 \%, 20$ sesquiterpenes totaling $52.9 \%$ and one aromatic esters making up $10.9 \%$. And the oil contains (E,E)-farnesyl acetate (19.0\%), $\alpha$-turmerone $(12.0 \%)$, benzyl benzoate $(10.9 \%)$ and $\gamma$ terpinene $(7.4 \%)$ that are as the major constituents. The volatile components of bullock's heart (A. reticulata) has been studied [11] and in their study the volatile components of bullock's heart were isolated by simultaneous steam distillation/solvent extraction and analyzed by GC/MS. Forty-nine compounds were identified in the fruits. The major volatiles in bullock's hearts are $\alpha$-pinene (28.3 ppm), $\beta$ pinene $(22.2 \mathrm{ppm})$ and germacrene $\mathrm{D}(12.5$ ppm) [11]. 
By GC and GC/MS the essential oil produced by hydrodistillation of Annona squamosa leaves was also investigated [4]. In their work eighteen compounds have been identified accounting for $86 \%$ of the oil. The oil of $A$. squamosa was made up of monoterpene hydrocarbons $\quad(2.5 \%), \quad$ sesquiterpene hydrocarbons $(76.0 \%)$ and oxygenated sesquiterpenes $\quad(7.1 \%)$. $\quad \beta$-caryophyllene (23.0\%), germacrene D $(21.3 \%)$, bicyclogermacrene $(8.5 \%)$ and $\beta$-elemene $(7.8 \%)$ are the major constituents of the oil. The volatile constituents of Annona squamosa $\mathrm{L}$. bark were identified from the essential oil obtained by steam distillation and studied by GC/MS. Six major components are identified as 1H-Cycloprop(e)azulene (3.46\%), germacrene D $(11.44 \%)$, bisabolene (4.48\%), caryophyllene oxide $(29.38 \%)$, bisabolene epoxide (3.64\%) and kaur-16-ene (19.13\%). The oil was also screened for its antimicrobial activity that is as exhibited a significant antimicrobial activity against Bacillus subtilis and Staphylococcus aureus [4]. The chemical composition of the fruit pulp of Annona squamosa growing in the Brazilian Amazon is also studied [2]. In their work the result was compared with data of specimens occurring in Southeast Asia. In accordance with the sweet taste of the fruit pulp the amounts of sugars are found to be quite high (58\% of dry mass) and the triglyceride concentration was found to be very low. The presence of the diterpenoid compound kaur-16-en-18-oic acid in a considerable amount $(0.25 \%$ of dry mass) was detected in the lipid fraction. The essential oil of the fruit pulp is obtained and its volatile constituents are identified by GC-MS. The major compounds are $\alpha$-pinene $(25.3 \%)$, sabinene $(22.7 \%)$ and limonene $(10.1 \%)$. The occurrence of the isoricinoleic acid previously reported in the seed oil could not be confirmed [2].

\section{REFERENCES}

1. Adams R. P., 2001: Identification of Essential Oil Components by Gas
Chromatography/Quadrupole Mass Spectrometry, Allured Publishing Corp. Carol Stream, IL., 456pp.

2. Andrade H. A., Zoghbi M. B., Maia G. S., Fabricius H. and Marx F., 2001: J. Food Composition and Analysis, 14(2): 227-232.

3. Ban N. T., 2000: Flora of Viet Nam, Vol. 1, Family Annonaceae, Science and Technics and Publishing House, Hanoi.

4. Chavan M. J., Shinde D. B., Nirmal S. A., 2006: J. Nat. Prod. Res., 20(8): 754 - 757.

5. Garg S. N., Gupta Deepti, 2005: Composition of the leaf oil of Annona squamosa L. in North India plains. J. Essent. Oil Research, 17(3): 257-258.

6. Joulain D. and Koenig W. A., 1998: The Atlas of Spectral Data of Sesquiterpene Hydrocarbons, E. B. Verlag, Hamburg, 658 pp.

7. Koek N. J., Westra L. T., Maas P. J. M., 1990: Studies in Annonaceae. XIII. The role of morphological characters in subsequent classifications of Annonaceae: a comparative survey. Taxon, 39: 16-32.

8. Leboeuf M., Cave A., Bhaumik P. K., Mukherjee B., Mukherjee R., 1982: Phytochemistry, 21: 2783-2813.

9. Ministry of Health, 1997: Vietnamese Pharmacopoeia, Medical Publishing House, Hanoi.

10. Ogunwande Isiaka A., Ekundayo A., Olusegun Olawore, Nureni O., Kasali Adeleke A., 1992: Zhongguo Zhongyao Zazhi, 17: 295-296.

11. Pino J. A., Aguero J., Marbot R., 2006: J. Essent. Oil Res., 13(2): 140-141.

12. Stenhagen E., Abrahamsson S. and McLafferty F. W., 1974: Registry of Mass Spectral Data, Wiley, New York, 3358 pp.

13. Takhtajan A., 1997: Diversity and Classification of Flowering Plants. New York Columbia University Press. 


\title{
THÀNH PHẦN HÓA HỌC TINH DẦU LOÀI NA (ANNONA SQUAMOSA L.) VÀ BİNH BÁT (ANNONA RETICULATA L.) Ở VIÊTT NAM
}

\author{
TRẦN MINH HỢI, ĐỖ NGOC ĐÀI, TRẦN ĐÌNH THÁ́NG
}

\section{TÓM TÁ́T}

Hàm lượng tinh dầu trong lá của loài na (Annona squamosa L.) và bình bát (Annona reticulata L.) ở Việt Nam lần lượt là 0,2 và $0,3 \%$. Bằng phương pháp sắc ký khí khối phổ liên hợp (GC/MS), 39 hợp chất được tách ra từ lá bình bát, chiếm $92,4 \%$ tổng lượng tinh dầu với các thành phần chính là $\beta$-elemen $(36,5 \%)$, germacren $\mathrm{D}(16,0 \%), \beta$-caryophyllen $(5,3 \%), \beta$-bourbonen $(4,7 \%)$ và $\alpha$-copaen $(4,3 \%)$. Sáu mươi tám hợp chất được tách ra từ tinh dầu lá loài na, chiếm $84,4 \%$ tổng lượng tinh dầu, trong đó $\beta$-caryophyllen $(20,0 \%)$, camphen $(11,5 \%), \alpha$-pinen $(4,3 \%), \alpha$-humulen $(3,7 \%), \alpha$-cadinol $(3,7 \%), \delta$-elemen $(3,5 \%)$, bicyclogermacren $(3,4 \%)$, cadina-1,4-dien $(3,4 \%), \beta$-elemen $(3,2 \%)$ và cyperen $(3,2 \%)$. 